\title{
Towards an Aesthetics of Belief in Covid19 Pandemic Time: Performatism in Brian Friel's Dancing at Lughnasa
}

https://doi.org/10.33806/ijaes2000.21.2.2

\author{
Mahasen Badra \\ Istanbul Gelisim University, Turkey
}

\begin{abstract}
At the threshold of the third millennium, the present article endeavors to contribute to the scholarly and academic discourse over a successor of postmodernism that began to decline since the late 1990s. The study proposes to approach Brian Friel's Dancing at Lughnasa (1990) from a post-postmodern perspective, to trace Friel's lifelong quest for belief. The juxtaposition of Catholic ideals, Irish Celtic myths and African tribal rituals in Lughnasa, demonstrates Friel's complicated attitude towards religion. The study also introduces performatism, a new cultural theory coined by Raoul Eshelman in 2000, as a suggested post postmodern paradigm for the new epoch. The focus will be on the "aesthetic belief", a pivotal ideal in performatism. It is based on the technique of double frames in which the author originates a state of compulsory mediated belief by enclosing the reader/audience into outer and inner frames. The study reveals that Lughnasa which represents the culmination of Friel's lifelong quest for faith, transcends the limited experience of aesthetic belief in Eshelman's theory, into a more universal aesthetics of belief. Albeit a promising post postmodern alternative, the transient belief experience that performatism offers proofs too scanty for a millennium that is inaugurated by an earthshattering event as the Corona pandemic.
\end{abstract}

Keywords: Belief, Brian Friel, Covid 19, Performatism

\section{Introduction}

And I hope that between now and my death I will have acquired a religion, a philosophy, a sense of life that will make the end less frightening than it appears to me at this moment (Brian Friel, 2000: 99).

Having the postmodern legacy of irony, skepticism and unbelief as an ideological background in an age of overwhelming secularism, performatism, a new theory in aesthetic and critical criticism is presented by Raoul Eshelman at the onset of the epoch as an alternative to postmodernism. As a proposed successor to postmodernism, performatism ventures into a tentative quest of an "involuntary" belief that is based on a temporal engagement in aesthetic experience. However, in a world that is staggering under universal threats including global warming, terrorism and an impending third world war, there came the fatal Corona virus pandemic to smash the earth, infecting millions and reaping the lives of hundreds of thousands ${ }^{1}$, and thus startling humanity into inquiring about serious issues of belief. In the universal wave of panic that is sweeping the world, the spirit of solipsism and irony that has permeated the secular postmodern paradigm, seems 
pointless as an ideational code of reference. The human conscience - as an instinctive reaction in times of real suffering - resorts to the metaphysical to seek shelter and to find an answer for that big question: WHY? As of late, Western theologians have no satisfactory answer; N. T. Wright writes; "Christianity Offers No Answers About the Coronavirus"(2020) and James Martin S.J. states: "There is no satisfactory answer to that question, which at its core is the question of why suffering exists, something that saints and theologians have pondered over the centuries. In the end, it is the greatest of mysteries."(2020) At the time when researchers, scientists and physicians are racing to find a medical formula to save the lives of people, the burden of finding a consoling belief formula to save their souls, is the responsibility of theologians, philosophers, thinkers, and cultural theoreticians.

With the world facing such a global trauma, world thinkers perhaps have got to heed calls for inclusion, coexistence and the "shared spheres" of the kind that Peter Sloterdijk has called for. Nowadays, his demand in 2009 for global solidarity acquires a prophetic air; "The history of the own that is grasped on too small a scale and the foreign that is treated too badly reaches an end at the moment when a global co-immunity structure is born, with a respectful inclusion of individual cultures, particular interests and local solidarities." (You Must Change Your Life: 451). Performatism takes such a philosophical integrating spirit as a background in its call for unity and wholeness in works of art; such a call that defies the "end of history" claims of the postmodernists and revives the Hegelian "geist" or the universal cultural spirit.

\subsection{Performatism and aesthetic belief}

The pivotal element that this study focuses on in performatism is the "aesthetic belief" ideal which distinguishes it from among the other competitive nominees to succeed postmodernism ${ }^{2}$. Far from being a battlefield for a belief/unbelief strife, or offering a resolution of the belief predicament in an age pervaded by secularism, performatism offers an ultimately alternate type of belief that is primarily meant to deflate postmodern irony and skepticism. Eshelman (2019) states that it is: "an epochal development that replaces postmodern irony and skepticism with artistically mediated belief and the experience of transcendence." The basic goal of performatism, Eshelman denotes, is "to choke off irony by forcing us to believe using aesthetic devices". It is based on enclosing the reader/audience into "coercive frames" that originate a state of compulsory belief inside the frame. This sort of "coercion" works through aesthetic forms (per formam), which is where performatism gets its name ("What is Performatism?", 2019). Contrary to the spirit of solipsism and aggression in postmodernism, performatism, Eshelman notes in an interview with Ag Apolloni, "... provides a free space where you can experience things like sincerity, love, transcendence, etc. under certain set conditions provided by art." (2014: 13) The term performatism does not derive from performing arts, but rather from the performance that such a kind of works demands from the reader/audience. We may compare it to what Coleridge (1817) called "poetic faith" or the "willing 
suspension of disbelief' as a way to stimulate the reader to accept the supernatural elements in poetry ${ }^{3}$.

\subsection{Authorial manipulation, wholeness and forced identification}

To achieve the goal of creating belief in the recipient, Eshelman advocates "authorial manipulation", allowing the author an open license to whatever aesthetic devices that may serve his or her purpose, i.e., to create a sense of belief in the reader. As a strategy to bridle the excessive propensity for fragmentation in postmodernism, Eshelman adopts principles of wholeness and unity through a unifying character or sign with which readers may identify. He states: "performatist works offer us a unified object, person, or situation inside the work that we intuitively identify with, and then rig the work as a whole so that we don't have any other choice but to accept this identification."(2019). Although Eshelman makes it clear that performatism does not mean performance in the theatrical sense, I believe that the theatre allows a live and interactive space for the sort of aesthetic experience demanded by performatism. As Maysoon Muhi states: "... no debate has taken place over the fact that theatre, since its beginning, holds up a truthful and salient mirror to society, reading a community and graphically revealing its political, social and economic reality." (2020: 2) Oddly enough, in his several attempts to delineate his theory, Eshelman never referred to the theatre, despite the endless resources that the theatre may afford to support the claims of performatism. He depended only on some film productions, novels and short stories by a group of continental writers. The very concept of identification is the core of Aristotle's idea of 'catharsis', a theatrical experience where the audience is enticed to accept the dramatic presentation as reality to identify with the tragic hero and reach, through pity and fear, a state of spiritual purgation. Perhaps a more radical version of this concept is found in Artaud's theatre of cruelty that is meant to give a transformative and shocking effect to the audience. For Artaud, the theatre represents - to use his words as quoted in Rick Arandale: "a believable reality inflicting [a] kind of [. . ] laceration" (2007: 105). The crux of performatism is to create an aesthetic experience however affected or suspicious and regardless of the devices or "frames" the author may use to impose belief on the reader. In "Performatism or the End of Postmodernism"(2000/2001) Eshelman states: "On the one hand, you're practically forced to identify with something implausible or unbelievable within the frame - to believe in spite of yourself - but on the other, you still feel the coercive force causing this identification to take place, and intellectually you remain aware of the particularity of the argument at hand."

Taking Yann Martel's Life of Pi (2002) as his example of a performatist film that won a worldwide success, Eshelman provides an example of a rather illogical narrative, loaded with interesting adventures and dubious details, that is preferred by readers and filmgoers for the suspense and ecstasy it arouses. The novel bears great resemblances to the sensational experience that a reader may have from reading The Arabian Nights with its reliance on myths, fantasies and tales of jinns and ghouls. Eshelman's query on the effect of $P i$, applies to both 
works: "given that we can never know for sure what is true, isn't it better to enjoy what is beautiful, good and uplifting rather than dwell on what is ugly, evil and disillusioning?" such works of art are not meant to address the logical faculties of the analytical mind; their realm lies beyond the rational domain and the aim is to make the reader experience a temporal state of believing in goodness, love and sincerity, however questionable the details are. Thus, irony and skepticism are pointless here, for such a type of works "shifts the framework of its argumentation from an epistemological plane to an aesthetic one". (2005/2006). As will be demonstrated further in the following pages, Friel adopts a similar attitude in Dancing at Lughnasa.

\subsection{The double frames}

From the technical point of view, performatism as above noted, endows the author with an endless authority to manipulate whatever devices may help "coerce" the audience to acquire the state of unification or belief. Central to performatism is the "double framing" technique that includes outer and inner frames. The "outer frame" refers to the whole idea of the work, the dogmatic assumption or the pivotal argument of the work of art, while an "inner frame" refers to what Eshelman calls "a synthetic, unified, object-focused projection" (2000/2001). It can be a character, a situation or a sign with which the reader/spectator unifies to reach belief and transcendence. Eshelman regards the "double frame" idea as his "main contribution to the project"(2019), however, the inner frame has its origin in T.S. Eliot's concept of the "objective correlative" as developed and expressed in his Essay on "Hamlet",(1919) where he argues that the best way to express a certain emotion is to find "a set of objects, a situation, a chain of events, which (will) be the formula of that particular emotion." (145) Friel used that technique widely in most of his play.

\subsection{The surprising effect}

Finally, performatism recreates history by making readers/audience experience a kind of change through surprising them and defying their expectations. Eshelman states: "Performatist narratives contain a narrative or thematic device that produces a surprising effect resulting in a change in the fictional world." (2019) Perhaps the most recent standard example of such a surprising effect is found in Parasite, the universally acclaimed film of the Korean Bong Joon-ho, that won the 2019 Oscars. The film has a socioeconomic message characterized by wholeness and sincerity and it is dominated by a breathtaking tone that couples with black comedy. Among the highly acclaimed reviewers of the film is Dave Calhoun (2019) who described it as "a dazzling work, surprising and fully gripping from beginning to end." The film's universal acceptance by the public and the cinema critics testifies to the fact that there came the need for something opposite to the postmodern ironic mode of denial and skepticism. Such an alternative approach is relevant to the theatrical experience in general and Brian Friel's theatre in particular. 


\subsection{The belief dilemma in in the West}

The dilemma of belief and unbelief in the Western mind, that began around the mid-nineteenth century, has been a recurrent issue that occupied the sensibility of many writers like Percy Shelley (1792-1822), George Eliot (1819-1880), Fyodor Dostoevsky (1821-1881) Thomas Hardy (1840-1928), Emily Dickinson (18301886), James Joyce (1882-1941) and Virginia Woolf (1882-1941). That dilemma stemmed from the dichotomy, or rather the conflict between the empirical disposition that pervaded the Western mind since the early nineteenth century on the one hand, and the innate need in the human heart, for the existence of a metaphysical "deity" on the other. As this is not the main objective of this study ${ }^{4}$, a slight reference to a few examples may suffice. In Percy Shelley's case, two years after the publication of "The Necessity of Atheism" (1811), he announced in a note to Canto VII of Queen Mab, "There Is No God. This negation must be understood solely to affect a creative Deity. The hypothesis of a pervading Spirit co-eternal with the universe remains unshaken." A more glaring sense of the chasm between the thirst for faith and the inquisitive mind that cannot find in Christianity reasonable answers for urgent questions shows itself in a letter by Dostoevsky to Mrs. Fronzivinia in 1854, he writes: "if someone proved to me that Christ is outside the truth,...then I should prefer to remain with Christ rather than with the truth." (quoted in Joseph Frank, 1983: 160) . As the list goes on, we may finish this section by referring to James Joyce's complicated relation with the Roman Catholic Church and his devotion to anti-religious free thinking. As demonstrated in a letter to Nora in $1904^{5}$ Joyce abandoned the church as a teenager; he tells her that he made a "secret war upon it when I was a student ..." but he kept it secret till the age of 22. At that time, he would "make open war upon it by what I write and say and do" (qtd. in Lernout, 2010: 6, 206). Lernout refers also to Joyce and Nora's refusal to marry in a Catholic church and their aversion to baptize their children. Even when he died, Nora refused an offer to arrange a funeral mass for him $(6,94)$.

That state of "warfare" between belief and unbelief and the sense of unsettlement that characterized the lives and works of such writers reflect a state of "grappling with God"(Lundin: 2014), having as a background the state of mind that preceded and followed Nietzsche's agonized announcement of the "death of God". Contrary to this sense of agony, the mode of thought that permeated the late twentieth century reflected an utter refutation of the idea of belief, with the prevalence of secularism and irony in the secularist minds that no longer lived the death-of-God trauma.

For many writers, critics and theorists, the absence of a deity and the denial of a divine origin of the Bible, resulted in searching for an alternative source of belief or another text of the truth. In America, around the mid-twentieth century, Wallace Stevens (1879-1955) developed a concept of the aesthetic experience as a substitute for the belief in God, a theory that is to be reinforced by the literary criticism of Frank Kermode and Northrop Fry who advocated that fiction should replace the sacred scriptures ${ }^{6}$. Poetry for Stevens is the alternate belief that is to replace divine revelation. 


\section{Poetry}

Exceeding music must take the place

Of empty heaven and its hymns,

Ourselves in poetry must take their place (1997: 137)

Likewise, other writers were seeking a similar path, each in his own way. As Roger Lundin (2014) states: "In England, in Ireland, and in exile, William Butler Yeats, Ezra Pound, and James Joyce were busy breaking new literary ground and forsaking the cultivation of overtly Christian concerns". The claim of fiction as a substitute for the Bible's legacy in the West is advocated at present by James Wood, the contemporary celebrated literary critic. In his collection of critical essays published in 1999 under the title The Broken Estate: Essays on Literature and Belief, he presents his views of the orthodox Christian belief as an old estate that is broken since the mid-nineteenth century and that no longer represents the cultural basis of belief for a group of novelists including Joyce and Virginia Wolf. In his New Republic essay on Herman Melville (1997), he depicts his creeds outright: "God has disappeared and returns as literature. ... Literature is the new church and Moby-Dick its Bible".

\subsection{The belief dilemma in Friel}

Friel's latest attitude towards religion as demonstrated in Dancing at Lughnasa, is best expressed - to use Ed Block Jr.'s (2000) words - as a "Post-Christian Christian" position. This is clearly revealed in the juxtaposition of Catholic ideals, Irish Celtic myths and African tribal culture in the play. His priesthood attempt at Maynooth College, at the age of 16 ended with his leaving the college two years later, and giving up the clerical career forever. At the age of 35 he declared that it was "an awful experience. It nearly drove me cracked. It is one thing I want to forget. I never talk about it, the priesthood."(2000: 21). Friel kept it as a private issue, yet the religious obsession kept haunting him and it stamped most of his dramatic output with a puzzling attitude to Christianity, oscillating between affirmation and denial and resulting in baffled attempts at what Block calls, "either a demolition of the sacred or an effort to salvage it."( 2000: 198). This was incarnated in his drama in a dual sense of attachment to and anger at the priest figure (Philadelphia Here I Come!), provocative religious allusions (Faith Healer, Wonderful Tennessee) and a relentless quest for belief (Dancing at Lughnasa).

For Friel, religion and politics were the major forces that formed the Irish identity and that nevertheless, deepened the split in the Irish character, especially for a Catholic Nationalist living among the Protestant Unionist majority in North Ireland. The rigidity that characterized the sense of belonging in the Irish character, as Friel states, was among the causes behind his faith dilemma: "And when I refer to Ireland as being inbred and claustrophobic and talked of the tortuous task of surveying the mixed holding I had inherited, I had in mind how difficult it is for an Irish writer to find his faith. He is born into a certainty that is cast-iron and absolute." (2000: 107). Politics and religion were the dominant 
themes in Friel's earlier plays, but in the 1990s he tended to avoid political themes in favor of spiritual and transcendental subjects. This spiritual quest began as early as 1979 in Faith Healer and it came to the fore with Dancing at Lughnasa (1990) and Wonderful Tennessee (1993). In those plays, Brian Friel does not seem to cherish Christianity as the only route for spiritual gratification and transcendence. Such a conviction led him in an early stage of his career to search for an alternative track; like many of the pre-mentioned artists, it was to the shrine of art that he was summoned to start his lifelong vocation. Tyrone Guthrie's invitation in 1963 for Friel to attend the opening of his new theatre in Minnesota offered him invaluable inspirations and self-assurance on the technical and thematic levels in the theatrical field. He describes the three-month stay as "traumatic" but it was for him a pilgrimage that inaugurated his "theoretical priesthood"(2000: 104). Thus he embarked upon an artistic career where he began to seek in art what he could not find in the church. His contact with the American cultural and artistic milieu continued and he was elected in 1996 as a member of the American Academy of Arts and Letters; such a contact made him subject to other far-reaching influences in thought and artistic career.

\subsection{Dancing at Lughnasa, an introduction}

Dancing at Lughnasa ${ }^{7}$ was premiered at the Abbey Theatre in April 1990 and was highly acclaimed by many critics as Friel's most successful play. It was presented on the theatres of Dublin, Glenties, London and New York and it won three Tony Awards in New York, including the Best Play of 1992. For many critics, it represents the culmination of his artistic prowess and theatrical innovation. The play revolves around the childhood memories of Michael (now an adult young man) during the Irish Lughnasa Festival near the end of summer in 1936. He is the narrator and the action is set at the Mundy sister's house at Donegal, a small village where his mother Chris and her four spinster sisters lived. The memories recall the effect of a newly obtained radio set on the five sisters, the Lughnasa festival ceremonies during late August and the arrival of the sickly father Jack, their brother, from Ryanga after a church service that lasted for 25 years. Another central memory is the long-awaited arrival of Gerry Evans, Michael's father by whom Chris has had Michael out of wedlock, after a precarious love affair. As the action is presented through the flashback technique, Michael tells the audience about the tragic end of each of the characters.

\subsection{Authorial manipulation}

Most of the formerly noted performative features can largely be traced in Dancing at Lughnasa where Friel's immanent presence as an author is vigorously felt from the first moment. His authorial manipulation is based on three main elements; certain unmistakably autobiographical details, the choice of the child Michael as the hero/narrator to be the single consciousness through which the past is revealed, and the trance effect that Friel craftily manipulates to stun the audience and engage them in a perfectly theatrical aesthetic experience. 
Dancing at Lughnasa comprises a clear autobiographical element that strikes us from the start by the dedication on the first page: "In memory of these five brave Glenties Women" (I). Here Friel refers to The McLoone girls, Friel's mother and her four sisters who lived in Glenties in Donegal. They become the Mundy sisters in the play. According to David Ward (2014) who found those details in Friel papers in the National Library of Ireland, Father Jack is modeled after "Fr Barney", Friel's uncle whom he describes as the "wee Donegal priest" who had come home "broken in health after 35 years of heroic service in the mission service in Uganda". The autobiographic stamp is still emphasized by setting the child Michael as the author/narrator. Fintan O'Toole rightly observes that Friel chose to make Michael the boy "the same age (seven) as he himself would have been in 1936."(1993: 211). The very act of dedication is in itself performative in character in the sense that it does what it says. In Paratexts Gerard Genette discusses dedication in a work of art as a paratextual content, "Dedicating a work is a public act that the reader is, as it were, called on to witness. A typically performative act ... for in itself it constitutes the act it is supposed to describe;" (1978: 134). These two devices; i.e., dedication and the narrator boy entice the audience to engage with the world of the Mundy sisters, and create a sort of authorial intimacy between Friel and his audience.

\subsection{Forced identification and unity}

The participatory confidential mode, with which Michael shares the memory of the five sisters' lives with the audience, lures the latter into a confidence with the narrator and disarms them from any detaching skeptical or analytical attitude; this leads to a sort of compulsory belief which Friel craftily achieves from the first moment. Michael's character as narrator encourages the audience to identify with him and endows the play with a unified view of the past. The sense of unity stems also from the fact that Michael is a narrator/participant at the same time. While narrating the story, he also speaks the lines of Michael the boy who is seen by all except the audience; we as spectators have to imagine his existence. When any of his aunts touches or kisses him - Friel directs - it should be through pantomime. Through this daring reality/illusion device, Friel wins his audience into believing the memory. In Act I, the Boy - whom we do not see - fools his Aunt Maggie with a non-existent rat:

Boy: Look out - there is a rat!

(She screams and leaps to her feet in terror.)

Maggie: Where? - Where? - Where? - Jesus, Mary and Joseph, where is it?

Boy: Caught you again, Aunt Maggie (8).

Thus, Friel explodes from the inside, Brecht's narrator that the latter originally adopted as a detaching device, and uses it to produce the opposite effect. Instead of detaching the audience - which is the ultimate goal of Brecht's epic theatre Friel manipulates Michael to create a common space with the theatre-goers and involve them in the world of the characters and perhaps of Friel himself. Both of 
the dedication and the child narrator contribute to what Sloterdijk calls the "bipolar intimacy" that refers - as Eshelman explains - to some "spheres" or frames that "encourage individuals to overcome their isolation and achieve a sense of trust towards another person." (2014)

\subsection{Michael, The dumb hero}

When asked in an interview by Ag Apolloni (2014) about the significance of the idiot-as-hero technique, Raoul Eshelman declares that it is an anti-postmodernism strategy to deflate the ironic skeptical mind. "it's just meant to destabilize the ironic conceits of erudite people." Friel's boy narrator outmatches Eshelman's idiot figure and exceeds him in effect. On the audience's part, the child figure is much more aptly accepted to identify with than the idiot figure. Sincerity, innocence and love are the expected emotional basis of the identification performance required from the audience. Still, in a way or another, the child's consciousness is relevant to the trance effect that allows Friel the freedom to create a lively entertaining experience. All the events and the characters presented on stage, flow from the mind of Michael the child, not the adult. Naturally, a child's outlook on the world of adults is characterized by a considerable amount of exaggeration, playfulness and emphasis on appearance, colors, and motion rather than on speech.

Michael remembers his father with a big straw hat and a walking stick; the most prominent activity that he remembers of him during his short visit is dancing with Chris and Agnes. His shock at the appearance of Father Jack as he first saw him, "shrunken and jaundiced with malaria" (75), and the African tribal dances and rituals that he performed in those days, are what dwell Michael's memory of the man. All he remembers about aunt Maggie are the jokes and the silly riddles she used to fool him with. The boisterous dance of his aunts to the radio music is what dominates his memory about those days in the past. The play opens and ends with two tableaux in which all the characters are cast in certain positions. In the final tableau, the colors are exaggeratedly bright with the pagan faces drawn on the boy's kites, "On each kite is painted a crude, cruel, grinning face, primitively drawn, garishly painted"(70). The golden light, the sweet music and the vivid colors suggest that the events of those two days in the summer of 1936 are associated in Michael's conscience with a pleasant golden time. Friel manages to cast a spell on his audience and to win them into moments of aesthetic belief through sound, gesture, music and dance rather than words.

\subsubsection{Aesthetic belief and Friel's developed concept of language}

Aesthetic belief is closely related to Friel's concept of the meaningless of language and its inadequacy to convey thoughts, feelings and memories. The core of aesthetic belief is to cast a spell on the audience and to win them into a state of forced belief. This is craftily achieved by Friel, not only through the spoken discourse, but also through the crafty manipulation of music, dance, gesture, colours, lights and all the artistic devices that the theatre can afford, to coerce the spectator into aesthetic belief. Some of Friel's plays like Philadelphia, Cass, 
Winners, The Freedom of the City and Faith Healer are based mainly on long speaking turns by highly eloquent characters such as Private Gar, Cass, Maggie and the "glib" Skinner. However, the latter stage of Friel's career has witnessed, as Elmer Andrews remarks, "a growing dissatisfaction with the inadequacy of words, an impatience with their duplicity"(1995: 210). As he developed his theatrical expertise, and perhaps as a consequence of his experience at Guthrie's theatre, Friel began to develop a concept of language close to that of Heidegger. F. C. McGrath denotes that Friel probably read George Steiner's book After Babel: Aspects of Language and Translations around 1979 before translating Chekhov's Three Sisters, in which Steiner was influenced by Heidegger's views of language. It undoubtedly reinforced Friel's notion of the "fictive nature of language."( 1997: 7). Moreover, in the prefatory program note to Translations Friel quoted a statement in Heidegger's essay, "Poetically Man Dwells" concerning the latter's ontological view of language. Heidegger's quoted statements were: "Man acts as though he were the shaper and master of language, while in fact language remains the mistress of man."(1971: 115). ${ }^{8} \mathrm{He}$ increasingly became convinced that reality dwells somewhere beyond the realm of human language, once you think you caught reality in the net of words, it vanishes because those words are inadequate to convey true meaning. Human language is not an appropriate vehicle to convey reality, on the contrary, language may be used as a mask to conceal it. This notion was effectively dramatized in Friel's The Freedom of the City (1973) that revolves around the notorious Bloody Sunday, where Friel shows how the perception of that violent act is influenced by social, religious and political prejudices. Avoiding the truth, each of the several voices commenting on the event presents a false interpretation to serve a preconceived biased attitude. The truth no longer exists in the refined language of each of the opposing parties. This is perhaps why in his later plays including Lughnasa, as will be shown in the following section, Friel illustrates a growing tendency towards inventing new means of expression, or as Andrews puts it, "a new language of the repressed unconscious, a new language of the body" (1995: 209).

\subsubsection{Signs, symbols and double frames in Lughnasa}

Dancing at Lughnasa teams with signs and symbols: the broken mirror, the radio, the dance, the fox, the white roaster, the kites, the hats, the cigarettes are all signifiers to unspoken meanings that cannot be overtly expressed. The fox refers to Danny Bradley, the "bastard" against whom Maggie warned her younger sister at the beginning of the play - but Rose, the "simple"-minded wouldn't listen to her.

Maggie: Everybody in the town knows that Danny Bradley is -

Rose: (To Maggie) And you are jealous, too! That's what's wrong with the whole of you - you're jealous of me! (6). 
During the Lughnasa festival, Danny, the "scut" preys over Rose's sexual innocence in the back hills. In a significantly symbolic last scene, the fox preys over Rose's white rooster that she brings on stage, "stained with blood", with ruffled feathers. Rose says: "Maggie warned me the fox was about again ... you were right Maggie" (67). The restrictions of the Catholic traditions that are no longer sufficient for the modern age are well symbolized by the broken mirror. The play opens with Chris wishing to "throw out" "this aul cracked thing", and to start wearing lipstick. Agnes answers her mockingly by quoting Kate's "Do you want to make a pagan of yourself!"(3), an answer that reaffirms the conflict between restraint as imposed by religion and freedom as offered by paganism, a leitmotif that is recurrent throughout the play with various originary signs including smoking, dancing, marriage and ritual. The newly acquired radio Maggie calls "Marconi" - symbolizes the new spirit of modernization that has already invaded the Mundy sisters' rural house. The swing music that it sends forth is an aspect of a rising revolt against settled customs and the Catholic tradition of primness and propriety that are on their way to dissolve, despite Kate's desperate attempts to preserve them.

Music and dance are central to the structure, characterization and theme of the play. It is through dance and music that Friel manages to create a holistic sign, an originary scene that serves as an inner frame to enclose the characters in a moment when they shed their ailments and transcend their emotional and social fetters. During the Lughnasa days, the Mundy sisters become aware of their sexual and social deprivation, which is expressed by their desire to go and dance in the harvest festival of Lughnasa: "Agnes: How many years have been since we were at the harvest dance? - At any dance? ... I'm only thirty-five. I want to dance." The idea was violently discarded by Kate, the Catholic prim:

Do you want the whole countryside to be laughing at us? ... mature women dancing? What's come over you all? And this is Father Jack home - we must never forget that-never! (13).

However, unable to resist the heavy beat of the raucous music coming out of the radio, the five sisters respectively surrender to the music in a dance that expresses turbulent, "deep and true emotion"(23). Maggie begins the dance:

... She is breathing deeply, rapidly. Now her features become animated by a look of defiance, of aggression ... she opens her mouth and emits a wild raucous "Yaaaah!" - and immediately begins to dance, arms, legs, hair, long bootlaces flying (21).

In turn, each of the sisters joins her and Kate who finally submits, performs a dance that is

totally concentrated totally private; a movement that is simultaneously controlled and frantic ... a pattern of 
action that is out of character and at the same time ominous of some deep and true emotion (22).

The significance of this scene lies in its remarkable manifestation of how the sisters undergo a state of "transformation" and manage to cast off (each in her peculiar way) the oppressive social frames that fitter their souls. Through corresponding to the music beat, they create their own individually constructed frames and transcend private tribulations.

Dancing as if language had surrendered to movement. ... Dancing as if the very heart of life and all its hopes might be found in those assuaging notes and those hushed rhythms and in those silent and hypnotic movements. (71)

In Lughnasa, the language of the body outmatches verbal discourse and stands as an "objective correlative" or "inner frame" to emotions and attitudes. That is remarkably incarnated in Jack who has lost his English memory owing to his long stay in Africa. Jack would prefer the beat of the tribal primitive music that addresses his senses, to the Catholic rational of the Word that celebrates restraint and order. The prominence of signs over words is finely given shape also during the hat-exchange ritual between Jack and Gerry. Jack puts on his ceremonial military uniform that is "very soiled, very crumpled" and his tricorn ceremonial hat "once white like the uniform, but now grubby, the plumage broken and tatty" (68). The miserable state of his clothes refers to the long forsaken traditional Irish identity.

The loss of Irish identity in the face of the other cultures and the sweeping change from the rural to the urban type, is a recurrent theme that shades many of Friel's plays, such as Translations, Philadelphia Here I Come, The Loves of Cass McGuire, as well as Dancing at Lughnasa. From a performative perspective, it is related to the double frames technique, as it represents the outer frame or the main theme around which the play revolves. This outer frame is pivotal in choosing the inner frame or the "devices" that the author manipulates to convey his theme to the audience. Such devices may include symbols, signs, ritual, costuming - as well demonstrated in the hat-exchange scene - or any other "inner frame". Friel complained, as quoted in Tom Murphy's A Paler Shade of Green: "We are rapidly losing our identity as a people ... We are no longer even West Britons; we are East Americans" (1972: 224). By 1990, Friel has come to develop a more tolerant attitude. In Lughnasa Friel has come to broaden his sense of identity to allow for other cultures and to open borders with the other. Christianity, Celtic myths and even paganism are presented on equal terms as potential spiritual realms through which one may reach transcendence and be "in touch with some otherness."(71) Kate, the Catholic prim, begins to realize that for all her desperate attempts to keep order, the "cracks" in that fragile edifice, Catholicism, can no longer be replenished: 
And then suddenly, suddenly you realize that hair cracks are appearing everywhere; that control is slipping away; that the whole thing is so fragile it can't be held together much longer. (35)

Although she knows that "leaping around a fire and offering a little hen to Uka or Ito, ... is not religion as I was taught it or indeed know it", she comes to acknowledge Jack's pagan practices as a his own "distinctive spiritual search"(63). That inclusive attitude is very near to what Eshelman declares to be a characteristic feature of the new epoch after postmodernism.

$\ldots$ in the new epoch it is not the "evil" principle of continued, random border transgression that is dominant, but rather the benevolent principle of drawing borders to create a quasi-sacral space in which an existing state can under certain circumstances be transcended". (2000/2001)

\subsection{Ritual from a performative perspective}

From the Catholic perspective, given that Jack who is coming back with a pagan "unchristian" culture represents the "perpetrator" and Gerry the representative of the Christian "victim", the hat swap ritual turns out to be the inner frame in which both men seek reconciliation, self-redemption and transcendence. On the moral level, the same scene may be put in another frame; Jerry, who violated the Christian traditions by having an out-of-wedlock sexual relation with Chris resulting in a love child, needs this exchange ritual to gain acceptance in Chris's family. Thus in one ritual, Friel presents a concrete sign that serves as a dual frame between perpetrator and victim, in order to make up for an unpleasant experience in the past and create a sense of self-redemption and social acceptance. It serves also to rewrite history, to break the sense of social alienation on Jack's part and to soften for Gerry the sense of denial in the orthodox milieu of Chris's family. It represents a post-postmodernist gesture indicating the sense of oneness, forgiveness and love. The hat swap ritual allows a space of coexistence and highlights the acceptance of the otherness of the "other". This scene conveys a message that is opposite to the famous hat-exchange scene between Didi and Gogo in Beckett's Waiting for Godot, that has a bitterly Nietzschean message, indicating the futility of the same act on the part of both the perpetrator and the victim in an absurd world pervaded by a silly hope of redemption with the alleged arrival of an ambiguous deity that will never come or perhaps has never existed.

\subsection{Memory, atmosphere and the sense of theodicy}

Contrary to plays like Philadelphia Here I Come! and The Loves of Cass McGuire that are based on memory and where the atmosphere is rather pathetic or even tragic, Lughnasa reflects the past through the memory of a person who is relatively outside the Mundy sisters' crisis. It is through this memory of Michael as a young boy that the unfavorable experiences are minimized and withdrawn into the subconscious, while the pleasant experiences are highlighted. For Michael, the memory frame is not a harassing experience as it is the case with 
other narrators like Cass McGuire or Frank Hardy; it is rather a peaceful sanctuary to which Michael resorts to transcend his present ailments as an adult, and redeem the innocence of significant moments in his childhood. Michael's memory of his father who abandoned him for years, is colored with tolerance and forgiveness. No sense of bitterness or antipathy is shown when he reveals that Gerry has already been married to another woman, having another boy of his age with the same name, Michael. A similar sense of forbearance marks Chris' tolerant reception of Gerry after his long absence. Friel chooses to dramatize in details the pleasant atmosphere of dances, jingles, songs and jokes, while reporting in Michael's speech, the distressing facts. The flight of Agnes and Rose, their loss of sustenance, and the deaths of Gerry, uncle Jack and Chris, are narrated with a calm matter-of-fact tone. For all of the various opposing forces that inflict the characters, the pervading emotional frame is a tranquilizing sense of peaceful resignation, transcendence and theodicy.

The play has a magical and mesmerizing effect; in Michael's final monologue Friel directs that the music of "It is Time to Say Goodnight" should "fade-in very softly, just audible". As for the lights, "the stage is lit in a very soft, golden light so that the tableau we see is almost, but not quite, in a haze" Moreover, as Michael continues his speech,

Everybody sways very slightly from side to side - even the grinning kites. The movement is so minimal that we cannot be quite certain if it is happening or if we imagine it (70-1).

It is not only "we" who are "not quite certain", Michael's mind also is so enthralled by the music which is "both heard and imagined", that he cannot differentiate between reality and illusion:

... and what fascinates me most about that memory is that it owes nothing to fact. In that memory atmosphere is more real than incident and everything is simultaneously actual and illusory.(71)

While Friel is influenced in his early plays by Brecht who endeavors to detach his audience from the action, he in those later plays, prefers the theatre of Artaud to enthrall the audience and involve them in a trance through ritual, dance and music. That is the core of the performative art as Eshelman (2005/2006) explains:

The ultimate frame of reference is performative, and not epistemological: ... it forces us, at least for the time being, to take the beautiful attitude of a believer rather than the skeptical attitude of a continually frustrated seeker of truth.

From this perspective, Dancing at Lughnasa can be regarded as a typical performative work of art. The child consciousness represents the unifying element 
that creates artistic tableaux or frames that lure the audience to believe and be engaged.

\section{Lughnasa, an aesthetics of belief for the epoch rather than an aesthetic belief}

However, Friel's art transcends Eshelman's temporal and confined frames; he aims at enticing his audience to live and believe the transcendental message of the play. Dancing at Lughnasa represents an aesthetics of belief, an art that embraces a vision, a sense of life that sustains love, co-existence and transcendence. Friel's art embraces a unifying faith for himself and the Irish "schizophrenic community"(2000, 103). His target was not to create the fleeting entertaining moments of artificial and dubious belief that Eshelman calls for. Throughout his dramatic career Friel created an art that is related to the here and now of the Irish people. This is the point where Friel's Dancing at Lughnasa exceeds the compulsory enclosed art-based belief experience in performatism into an aesthetics aiming at creating a true sense of belief.

Friel's washed-up experience of priesthood disillusioned him of Catholicism but not of the idea of religion and though some of his plays can be taken as a critique of the Catholic ideal, he never abandoned religion as an "enriching" spiritual power. His sense of religion is widened to include all sorts of "distinctive spiritual search." With no consoling formula of belief, Friel, like many novelists and poets, was a devout worshiper at the altar of art. A comprehensive view of his art yields an aesthetics of belief, a new religion where the essence of reality can be found "in those assuaging notes and those husked rhythms and in those silent and hypnotic movements"(71). Dancing to folk music, circling around a fire in a pagan ritual, releasing a colorful kite for a child may offer a spiritual sense of transcendence as uplifting as circling round a Kaaba, swaying opposite a Wailing Wall or attending a Sunday Mass. In his own niche of art, Friel was ascending "with eyes half closed", in a spiral upslope movement to new and wide horizons with "golden lights", where everyone has a place, where soft music is heard and where the "garish grinning faces" on his kites "whisper private and sacred things".

For all the overwhelming spread of secularism during the last half of the twentieth century, it began gradually to recede with the eclipse of postmodernism; scholars like Roger Lundin raised calls for "believing again"9 and theologians like Rice Brooks and William Lane Craig came to announce that "God Is Not Dead Yet" ${ }^{\prime 10}$. Moreover, with the rise of contemporary theological philosophy, a considerable number of figures in the academia ended with rejecting postmodernism. Headed by John Milbank, a group of contemporary English theologians and scholars founded radical orthodoxy, a theology with interdisciplinary realms where religion converges with culture, history, politics and language, thus resurrecting the ideals of unity and goodness as opposed to fragmentation and aggressiveness in postmodernism ${ }^{11}$. The post-postmodern acknowledgment of the metaphysical as a way to understand the world is shared by a varied group of cultural theorists, scientists and philosophers including Noam 
Chomsky, Albrecht Wellmer, Alan Sokal, Thomas Nagel and Camilla Paglia. The latter two condemned postmodernism as "Fashionable Nonsense" and a "plague upon the mind and the heart." 12

The postmodern legacy of skepticism, irony and secularism that pervaded the last half of the previous century, has been of no avail in times of real earthshaking ordeals. Nowadays, with the overrunning fear caused by the Covid 19 pandemic, the pressing need for the spiritual and the metaphysical is raised by many. Since an early phase of the pandemic, The World Health Organization published an Interim Guidance encouraging "the religious leaders and faith-based communities in the context of COVID-19" to support their communities by encouraging them "to take steps to manage their stress and to keep up hope during such times of isolation, fear, and uncertainty." Among the suggested procedures is "reading sacred texts and guidance from their respective faith traditions".(4) Rabbi Chaim Bruk, in an interview with Lindsay Schnell (2020) says: "I don't care if you're the greatest atheist in the world, something of this magnitude requires introspection on some level, and there will be a spiritual component to that."

\section{Conclusion}

The present study is the first to introduce and to probe Raoul Eshelman's new theory of performatism as a possible post-postmodern paradigm for the new epoch. Applying Eshelman's performatist assumptions to the theatre, the study allows a new and plausible perfectly artistic venue for the new theory. Brian Friel's Dancing at Lughnasa is handled as a touchstone for performatism; and a detailed account of the major theoretical ideals and technical claims of the theory are explored. It is worth noting that paly was premiered in 1990 - a timing that coincides with the period when postmodernism is thought to have begun to recede. The detailed analysis of the play validates the literary claims of Eshelman's theory and proves that from the technical perspective, Dancing at Lughnasa can be regarded as a typical performative work of art. By choosing a child as a hero/narrator and through applying a semi-Artaudian trance effect, Brian Friel manages to demonstrate a perfect authorial manipulation, to involve his audience in a theatrically rich aesthetic experience and to achieve a typical performative aesthetic belief experience. From a performatist point of view, the character of Michael as a hero/narrator achieves manifold goals: the child is an appropriate figure that can easily arouse the sense of love, sincerity and innocence, thus outmatching Eshelman's dumb hero. Moreover, by speaking confidentially to the audience about his own memories as a seven-year-old child, he manages to win their trust and to disarm them from any skeptical inclinations, thus leading them to a state of forced identification and compulsory belief. The double framing technique is clearly demonstrated in the play through Friel's developed concept of the adequate language for the theatre. The sense of nostalgia for the forsaken rural Irish identity can be regarded as the outer frame of the play, while the skilled use of concrete signs, gesture, dance, music, colours and ritual, 
represents the inner frames that enclose the spectator and coerce him/her into a state of belief and transcendence.

This essay presents a tentative view to participate in the ongoing academic and cultural discourse that is to crystalize a reliable and sustainable view of the world today. The crux of the present study is the revival of the idea of belief as a backdrop of creating and criticizing works of art in the new epoch. The study does not claim Friel for the new era, nor does it hail performatism as a well-developed and a refined literary and cultural paradigm for the new epoch, a too-early claim for any theory at present. It attempts rather to presents a critique of performatism through applying its assumptions on the belief system in Friel as presented in one of his masterpieces. While Friel's lifelong quest for belief has yielded a universal humanistic concept that is incarnated in Dancing at Lughnasa, the ideal of aesthetic belief that Eshelman advocates is limited to an ephemeral experience that does not surpass the boundaries of art; Eshelman's call for an art-based and short-term belief experience, does not address, or provide a sensible response to the scary down-to-earth variables in the new epoch. Nevertheless, his theory has an interesting aspect about it, i.e., it is the first critical and literary theory that valiantly defies the stubbornly long cherished ideological ideals of postmodernism, particularly irony and skepticism that are the foundations of secularism. Performatism is tackled here as a counter postmodern frame of thought that hails ideals of belief, sincerity, wholeness and coexistence in a world thwarted by a collapsed belief system which has yielded the bitter fruits of melancholy, solipsism and separatism. ${ }^{13} \mathrm{We}$ may conclude by stating that while performatism provides a technically innovative critical approach to the text, its core rationale needs a sort of promotion to provide a cultural view relevant to the age. For performatism to claim the position of a new paradigm, it has to revise its cultural foundation stone and to widen its ideological scope to concord with the steadily rising - however still evolving - transcendental mode of thought. ${ }^{14}$

\section{Notes}

1. This article was finished several months after March 11, 2020, the date the World Health Organization declared Covid 19 as a pandemic. According to a running tally of WHO website, the total death toll as of December 7 exceeded one million, five hundred and forty thousand, with confirmed infected cases exceeding 67 million around the world.

2. With only two decades behind, a consensus upon a definite successor to postmodernism in the new millennium is still a matter of academic and critical discourse. Serious attempts include Turner's "postpostmodernism", Epstein's “trans-modernism", Gans's "postmillennialism", Kirbey's "pseudo-modernism" or "digi-modernism" and Vermeulen and van de Akker's "metamodernism".

3. See Coleridge, Biographia Literaria, 1817, Chapter XIV. 
4. For more on that ideological struggle and its consequences in art and critical theory see Altholz, Josef L. 1988. 'The Warfare of Conscience and Theology' In Gerald Parsons. ed. Religion in Victorian Britain, Vol. IV: Interpretations. Manchester \& New York: Manchester University Press, and Roger Lundin, (2014). 'Doubt and belief in literature'

5. Quoted in Geert Lernout's (2010) Help My Unbelief: James Joyce and Religion.

6. See Frank Kermode, The Sense of an Ending: Studies in the Theory of Fiction (London: Oxford University Press, 1967) and Northrop Frye, The Secular Scripture: A Study of the Structure of Romance. England: Harvard University Press, 1976

7. Dancing at Lughnasa was the subject - among other plays by Friel - of my Ph.D dissertation, Supra-realism in Selected Plays by Brian Friel, 2001.

8. In Albert Hofstadler's translation, "Man acts as though he were the shaper and master of language, while in fact language remains the master of man."(1971)

9. Believing Again: Doubt and Faith in a Secular Age, 2009.

10. Rice Brooks, God's Not Dead: Evidence for God in an Age of Uncertainty, 2013.

11. Radical Orthodoxy. A New Theology. Edited by John Milbank, Catherine Pickstock, and Graham Ward (1999)

12. Alan Sokal and Jean Bricmont, Fashionable Nonsense (1997). Camilla Paglia "Post: Modernism is a Plague upon the Mind and Heart"(2015)

13. These words are written, by mere coincidence, at a time when the Moslems in France are being subjected to intolerance and discrimination under the Islamophobiac separatist right-wing policies of Emmanuel Macron.

14. In some phase of writing this article, I was given valuable advice, concerning the manuscript organization, by Marshall Brown, professor of English and Comparative Literature at the University of Washington and the editor of Modern Language Quarterly Journal.

Mahasen Badra

Istanbul Gelisim University

ORCID Number: 0000-0002-2125-3643

Email: mmmbmahasen@gelisim.edu.tr

\section{References}

Andrews, Elmer. (1995). The Art of Brian Friel. London: Macmillan Press Ltd. Arandale, Rick. (2007). 'Artaud and the concept of drama in theology'. New Black Friars. Vol 88. No 1013. January. 100-112. 
https://www.jstor.org/stable/43251106?seq=1\#metadata info tab content $\underline{\mathrm{s}}$

Block, Ed Jr. (2000). 'Brian Friel's Faith Healer as post-Christian Christian drama'. Literature and Theology. Vol.14. No.2. June. 189-207 https://www.jstor.org/stable/23924882?seq=1\#metadata_info tab_content $\underline{\mathrm{S}}$

Calhoun, Dave. (2019). 'Parasite'. Timeout. May 22. https://www.timeout.com/london/film/parasite-2019

Eliot, T.S. (n.d.) Selected Essays. London: Faber and Faber Ltd.

Eshelman, Raoul. (2019). 'What is performatism?'. Performatism.de. July 29. https://performatism.de/What-is-Performatism

Eshelman, Raoul. (2014). 'Performatism, the epoch after postmodernism'. In Ag Apolloni. Ed. Symbol: A Cultural Review. No2. https://www.scribd.com/document/351899940/Symbol-10

Eshelman, Raoul. (Fall 2005/Winter 2006). 'After postmodernism: performatism in literature', Anthropoetics. 11, no. 2 http://anthropoetics.ucla.edu/ap1102/perform05/

Eshelman, Raoul. (Fall 2000/Winter 2001). 'Performatism or the end of postmodernism'. Anthropoetics 6, no. 2. http://anthropoetics.ucla.edu/ap0602/perform/

Frank, Joseph. (1983) Dostoevsky: The Years of Ordeal, 1850-1859 (Princeton, NJ: Princeton University Press)

Friel, Brian. (1999). Dancing At Lughnasa in Brian Friel: Plays 2. London: Faber and Faber Limited.

Friel, Brian. (2000). (2003). Brian Friel in Conversation, edited by Paul Delany. The United States of America: The University of Michigan Press. https://books.google.com.tr/books?hl=tr\&id=UQf68KdXAYIC\&q=Irish\# $\mathrm{v}=$ snippet\&q$=$ Irish \&f $=$ false

Genette, Gerard.(1978). (1997). Paratexts: Thresholds of Interpretation. Trans. Jane E. Lewen. Literature, Culture, Theory 20. General eds. Richard Macksey and Michael Sprinker. Cambridge: Cambridge University Press.

Heidegger, Martin. (1971). Poetry, Language, Thought. Trans., Albert Hofstadler, (New York: Harper and Raw Publishers.

Lernout, Geert. (2010). Help My Unbelief: James Joyce and Religion (New York: Continuum)

Lundin, Roger. (2014). 'Doubt and belief in literature', The Oxford Handbook of Religion and the Arts. ed. by Frank Burch Brown. Feb. https://www.oxfordhandbooks.com/view/10.1093/oxfordhb/97801951766 74.001.0001/oxfordhb-9780195176674-e-032

Martin, James S.J. (2020).'Faith in the time of Corona virus'. America. The Jesuit Review, March 13. https://www.americamagazine.org/faith/2020/03/13/faith-timecoronavirus 
McGrath, F. C. (1997). 'Brian Friel and the Irish art of lying'. In William Kerwin. ed. Brian Friel: A Casebook. New York and London: Garland Publishing Inc. 3-12.

Muhi, Maysoon Taher. 'The Deeper Wounds: Living in the Trauma Zone in Jawad Al-Assadi's Baghdadi Bath and Mithal Ghazi's A Feminine Solo'. International Journal of Arabic-English Studies (IJAES), Vol. 20, No.2, 2020. https://doi.org/10.33806/ijaes2000.20.2.7

Murphy, Tom. (1972). 'Two playwrights with a single theme', in Des Hockey and Gus Smith. Eds. A Paler Shade of Green. London: Leslie Frewin.

O'Toole, Fintan. (1993). 'Marking time from Making History to Dancing at Lughnasa'. In Alan J. Peacock. ed. Achievement of Brian Friel. Gerrards Cross: Colin Smythe. 202-14.

Schnell, Lindsay. (2020).'Is the coronavirus an act of God? Faith leaders debate tough questions amid pandemic'. USA TODAY. April 2.

Shelley, Percy. (1832). Queen Mab, a philosophical poem, with notes. https://books.google.com.tr/books?id=-

7UDAAAAQAAJ\&printsec $=$ frontcover\&hl=tr\&source $=$ gbs_ge summar $\mathrm{y} \_\mathrm{r} \& \mathrm{cad}=0 \# \mathrm{v}=$ snipp

Sloterdijk, Peter. (2009). (2013). You Must Change Your Life. Trans. by Wieland Hoban. Cambridge: Polity Press.

Stevens, Wallace. (1997). Collected Poetry and Prose. Frank Kermode and Joan Richardson. Eds. New York: Library of America. https://books.google.com.tr/books?redir_esc=y\&hl=tr\&id=COuwAAAAI AAJ\&focus $=$ searchwithinvolume \&q=empty + Heaven

Ward, David. (2014).'Dancing at Lughnasa: the evolution of a masterpiece, step by step'. The

Guardian.

April.

https://www.theguardian.com/stage/2014/apr/01/dancing-at-lughnasamasterpiece-theatre-by-the-lake

Wood, James. (1997). 'The all of the if: Moby-Dick is the great dream of mastery over language'. New Republic. March 17. https://newrepublic.com/article/122388/all-if-james-wood-life-hermanmelville

World Health Organization, (2020) Practical considerations and recommendations for religious leaders and faith-based communities in the context of COVID-19. April 7.

https://www.who.int/publications/i/item/practical-considerations-andrecommendations-

for-religious-leaders-and-faith-based-communities-in-the-context-of-covid19 ?

Wright, N. T. (2020). 'Christianity offers no answers about the coronavirus. It's not supposed to'. Time. March 29. https://time.com/5808495/coronaviruschristianity/ 